\title{
Open Lung Recruitment untuk Pasien Udem Paru Akut Pasca Operasi Sesar
}

\author{
Dwiana Sulistyanti ${ }^{1}$, Yusmein Uyun ${ }^{2}$ \\ ${ }^{1}$ Bagian SMF Anestesiologi dan Terapi Intensif Fakultas Kedokteran Universitas Mulawarman-RSU AW Syahranie \\ Samarinda, ${ }^{2}$ Bagian SMF Anestesiologi dan Terapi Intensif Fakultas Kedokteran Universitas Gadjah Mada-RSUP \\ Dr. Sardjito Yogyakarta
}

\begin{abstract}
Abstrak
Udem paru akut pada wanita hamil merupakan kejadian yang jarang tetapi merupakan kejadian yang dapat mengancam jiwa. Meskipun merupakan kejadian yang jarang terjadi tetapi berhubungan dengan meningkatnya resiko pada ibu juga meningkatkan morbiditas dan mortalitas janin. Beberapa faktor resiko yang diidentifikasikan dapat menyebabkan udem paru: preeklamsi atau eklamsi, infeksi yang berat, penggunaan obat tokolitik, kelebihan cairan dan kehamilan ganda. Selain itu, perubahan fisiologi yang berhubungan dengan kehamilan mungkin bisa menjadi penyebab udem paru pada wanita hamil. Ventilasi mekanik efektif meningkatkan kandungan oksigen dan menurunkan trauma pada paru. Open lung recruitment dapat meningkatkan oksigenasi pada pasien dengan udem paru akut, dapat menurunkan indeks cairan ekstravaskuler paru, meningkatkan pengembangan paru dan menurunkan tekanan pada jalan nafas. Laporan kasus ini menjelaskan tentang penanganan udem paru akut pada wanita muda pasca operasi sesar atas indikasi preeklamsi, dimana dilakukan open lung recruitment saat pasien dirawat di ruang ICU, pasien dirawat selama hampir 2 minggu dan pulang dalam keadaan baik.
\end{abstract}

Kata kunci: open lung recruitment; udem paru akut

\section{Open Lung Recruitment for Patient Acute Pulmonary Edema Post Caesarean Section}

\begin{abstract}
Acute pulmonary edema in pregnant women is a rare but life-threatening event. Although it is a rare event, but it is associated with an increased risk for the mother as well as increasinh fetal morbidity and mortality. Several indentified risk factors can cause pulmonary edema : preeclampsia or eclamsia, severe infections, use of tocolytic drugs, fluid overload, and multiple pregnancies. In adition, physiological changes related to pregnancy may be a cause of pulmonary edema in pregnant women. Mechanical ventilation effectively increases oxygen content and reduces trauma to the lungs. Open lung recruitment can increase oxygenation in patient with acute pulmonary edema, can reduce the pulmonary extravascular fluid index, increase lung development, and reduce pressure on the airway. This case report describes the management of acute pulmonary edema in young women post-operative cesarean section for indications of preeclampsia, where open lung recruitment is performed when the patient is treatedin the ICU, the patient is treated for almost two weeks and return home in good condition.
\end{abstract}

Key words: acute pulmonary oedema, open lung recruitment 


\section{Pendahuluan}

Udem paru akut pada wanita hamil merupakan kejadian yang jarang tetapi merupakan kejadian yang dapat mengancam jiwa. Meskipun merupakan kejadian yang jarang terjadi tetapi berhubungan dengan meningkatnya morbiditas dan mortalitas pada ibu dan janin. ${ }^{1}$ Beberapa penyakit spesifik selama kehamilan dapat menjadi faktor resiko terjadinya udem paru akut. Penyakit spesifik tersebut seperti preeklamsi dan eklamsi, kardiomiopati, sepsis, persalinan prematur, emboli air ketuban dan emboli paru. Insiden udem paru pada wanita dengan preeklamsi sekitar 3\%, dimana $70 \%$ terjadi setelah persalinan. Selain faktor resiko diatas masih ada beberapa hal yang diduga menjadi penyebab udem paru, antara lain tranfusi darah, serta penggunaan oksitosin peripartum walaupun tanpa disertai adanya kejadian kelebihan cairan dalam vaskuler ataupun penyakit jantung. Walaupun tidak ada terapi yang spesifik untuk menghentikan proses inflamasi yang terjadi pada udem paru, penanganan udem paru difokuskan pada 3 hal penting yaitu: mencegah lesi paru secara iatrogenik, mengurangi cairan di dalam paru dan mempertahankan oksigenasi jaringan.

Pendekatan terapi terkini untuk udem paru adalah meliputi perawatan suportif, bantuan ventilator dan terapi farmakologis. Salah satu tehnik yang digunakan dalam penatalaksaan udem paru adalah open lung recruitment, dimana tehnik ini dapat meningkatkan oksigenasi pada pasien, dapat menurunkan indeks cairan ekstravaskuler paru, meningkatkan pengembangan paru dan menurunkan tekanan pada jalan nafas. Tetapi penggunaan tehnik ini sampai saat ini masih kontroversial.

\section{Kasus}

\section{Anamnesa}

Perempuan, 29 tahun, pasca operasi sesar hari ketiga atas indikasi preeklamsi berat, datang ke UGD RS AW Syahranie (tanggal 8 November 2014 jam 01.00 WITE) dengan rujukan dari RS PKBI dengan penurunan kesadaran dan sesak nafas. Dari anamnesa dengan petugas medis yang mengantarkan, pasien sudah mendapatkan tranfusi darah whole blood 3 kantong atas indikasi anemia pasca operasi sesar. Hasil pemeriksaan hemoglobin pasca tranfusi adalah $8,7 \mathrm{gr} \%$. Infus terpasang dari rumah sakit PKBI adalah drip aminopilin dalam RL 500 cc.

\section{Pemeriksaan Fisik}

Saat dilakukan pemeriksaan fisik didapatkan kesadaran somnolen dan tampak sianosis, gurgling (+), tekanan darah 100/70 $\mathrm{mmHg}$, laju nadi $140 \mathrm{x} /$ menit, laju nafas $48 \mathrm{x} /$ menit dengan saturasi $40 \%$, kemudian dilakukan suctioning dan bagging dengan $\mathrm{O}_{2} 10$ liter/menit saturasi naik $70 \%$. Pemeriksaan paru, sonor seluruh lapangan paru, auskultasi ditemukan ronki basah diseluruh lapangan paru. Extremitas udem, sianosis, clubbing finger (-). Dilakukan pemeriksaaan laboratorium, hasilnya hemoglobin 10 gr \%, lekosit $24.000 / \mu \mathrm{L}$, hematokrit $29,8 \%$, trombosit $309.000 / \mu \mathrm{L}$, ureum $47,4 \mathrm{mg} / \mathrm{dl}$, kreatinin $1,2 \mathrm{mg} /$ $\mathrm{dl}$, gula darah $98 \mathrm{mg} / \mathrm{dl}$, natrium $142 \mathrm{mmol} / \mathrm{L}$, kalium 4,2 mmol/L, Chloride $114 \mathrm{mmol} / \mathrm{L}$. Hasil analisa gas darah : $\mathrm{pH} 7,30, \mathrm{PCO}_{2} 45, \mathrm{PO}_{2} 19, \mathrm{BE}$ $-4,5, \mathrm{tCO}_{2} 23,2 \mathrm{HCO}_{3} 21,9$.

\section{Pengelolaan Anestesi}

Kemudian dilakukan intubasi dengan fentanil $100 \mu \mathrm{g}$, midazolam $5 \mathrm{mg}$ dan rokuronium $40 \mathrm{mg}$. Setelah itu diberikan injeksi dexametason $8 \mathrm{mg}$ dan injeksi furosemid $20 \mathrm{mg}$.

\section{Pasien didiagnosa pasca SC hari ke 3 dengan} udem paru

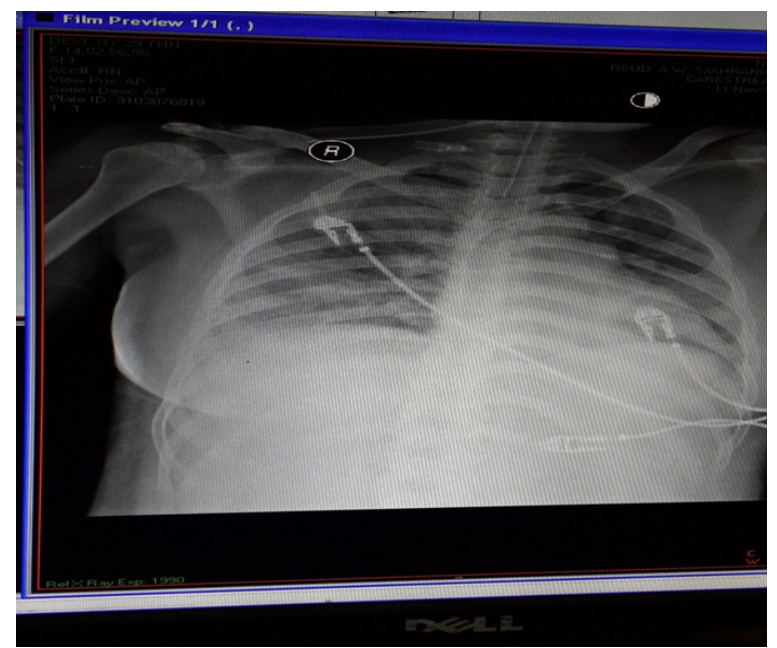

Gambar 3. Gambaran Radiologi Thorax AP saat Pasien Masuk UGD 
Catatan Kemajuan:

\begin{tabular}{|c|c|c|}
\hline Tanggal & Kondisi Pasien & Terapi \\
\hline $8-11-2014$ & Kesadaran komposmentis, sianosis (-) & Ventilator mode P-SIMV PS 15, \\
\hline (Hari ke-1) & $\begin{array}{l}\text { TV: TDS } 105-170 \mathrm{mmHg}, \text { TDD } 70-83 \\
\text { mmHg, HR } 89-97 \mathrm{x} / \mathrm{menit}, \mathrm{RR} 27-42 \mathrm{x} / \\
\text { menit, t: } 36-38,8^{\circ} \mathrm{C} \text {, Saturasi : } 80-90 \% \\
\mathrm{Lab}: \mathrm{Hb} 8,6 \mathrm{~g} / \mathrm{dL}, \mathrm{WBC} 22.500 / \mu \mathrm{L}, \mathrm{Ht} \\
25,7 \% \text {, PLT } 260.000 / \mu \mathrm{L}, \mathrm{GD} 102 \mathrm{mg} / \mathrm{dL} . \\
\text { Keseimbangan cairan: - } 1280 \mathrm{cc} / 24 \mathrm{jam} .\end{array}$ & $\begin{array}{l}\text { PEEP 10, RR setting 12-18, } \mathrm{FiO}_{2} 100 \% \\
\text { KaEN 3B } 80 \mathrm{cc} / \mathrm{jam} \\
\text { Neomune } 6 \text { x } 100 \mathrm{cc} \\
\text { Injeksi meropenem } 2 \times 1 \text { gram } \\
\text { Parasetamol infus kalau perlu } \\
\text { Injeksi furosemid } 40 \mathrm{mg} \text { extra } \\
\text { Morpin } 1 \mathrm{mg} / \text { jam diturunkan menjadi } 0,5 \mathrm{mg} / \\
\text { jam, drip aminopilin dihentikan. Pasang NGT dan } \\
\text { pasang CVP }\end{array}$ \\
\hline $\begin{array}{l}\text { 9-11-2014 } \\
\text { (Hari ke-2) }\end{array}$ & 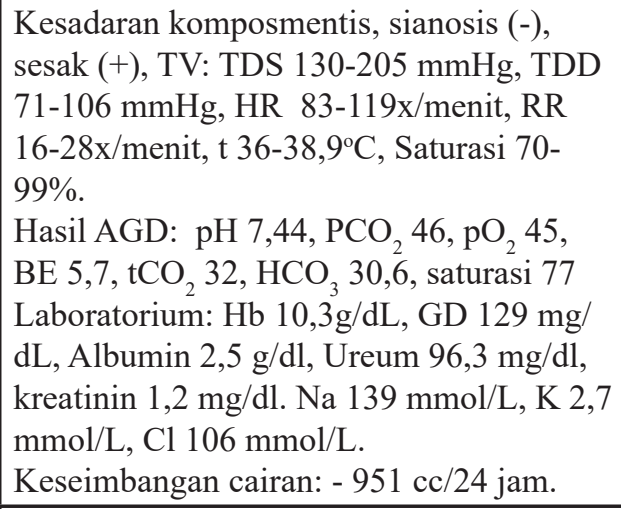 & $\begin{array}{l}\text { Ventilator mode P-SIMV PS } 15 \text {, PEEP } 10 \text {, RR set- } \\
\text { ting } 12-18, \mathrm{FiO}_{2} 100 \% \text {. } \\
\text { Ambil darah untuk analisa gas darah } \\
\text { Dilakukan open lung recruitment dengan sedasi } \\
\text { midazolam } 5 \mathrm{mg} \text { dan pelumpuh otot rokuronium } \\
50 \mathrm{mg} \text {. Setelah dilakukan open lung recruitment, } \\
\text { mode ventilator PC dengan PS } 16 \text {, PEEP } 20 \text {, FiO } \\
100 \% \text { bisa diturunkan bertahap hingga } 50 \% \text { dengan } \\
\text { target saturasi } 95-96 \% \text {. KaEN } 3 \mathrm{~B} 80 \mathrm{cc} / \mathrm{jam} \text {, } \\
\text { neomune } 6 \times 100 \mathrm{cc} \text {, injeksi meropenem } 2 \times 1 \text { gram, } \\
\text { injeksi furosemid } 20 \mathrm{mg} \text { extra, morpin } 0,5 \mathrm{mg} / \mathrm{jam} \text {, } \\
\text { midazolam } 2,5 \mathrm{mg} / \mathrm{jam} \text {, rokuronium } 15 \mathrm{mg} / \mathrm{jam} \text {. }\end{array}$ \\
\hline $\begin{array}{l}\text { 10-11-2014 } \\
\text { (Hari ke-3) }\end{array}$ & $\begin{array}{l}\text { Kesadaran tersedasi } \\
\text { hemodinamik relatif stabil }\end{array}$ & $\begin{array}{l}\text { Dilakukan weaning ventilator pasca open lung } \\
\text { recruitment, terutama penurunan PEEP dengan } \\
\text { memperhatikan hemodinamik dengan target } \\
\text { saturasi 95-100\%. } \\
\text { Mode ventilator menjadi P-SIMV PS 18, PEEP 8, } \\
\text { setting RR 13, FiO } 50 \% \text {. } \\
\text { Dilakukan pemasangan CVP, nilai CVP } 14 \mathrm{~cm} \\
\mathrm{H}_{2} \mathrm{O} \text {. } \\
\text { Terapi relatif masih sama, untuk KaEN 3B ditu- } \\
\text { runkan jadi 70cc/jam } \\
\text { Diberikan nebulizer (Nacl dan bisolvon) tiap } 3 \text { jam } \\
\text { Suction berkala } \\
\text { Chest physiotherapi } \\
\text { Ambroksol 3x1 cth } \\
\text { Omeprazole } 1 \text { x } 40 \mathrm{mg}\end{array}$ \\
\hline $\begin{array}{l}11-11-2014 \\
(\text { Hari ke-4) }\end{array}$ & $\begin{array}{l}\text { Kesadaran tersedasi } \\
\text { Hemodinamik relatif stabil, saturasi } 97- \\
\text { 100\%. Suhu pasien kadang-kadang febris. } \\
\text { CVP } 12 \mathrm{cmH}_{2} \mathrm{O} \text {. } \\
\mathrm{Lab}: \mathrm{Hb} 9,5 \mathrm{~g} / \mathrm{dL}, \mathrm{WBC} 20.500 / \mu \mathrm{L}, \mathrm{Ht} \\
27,1 \%, \mathrm{PLT} 345.000 / \mu \mathrm{L}, \mathrm{GD} 98 \mathrm{mg} / \mathrm{dL} \text {, } \\
\text { Ureum } 64,8 \mathrm{mg} / \mathrm{dl}, \mathrm{Kreatinin} 1,8 \mathrm{mg} / \mathrm{dl} \text {, } \\
\mathrm{Na} 142 \mathrm{mmol} / \mathrm{L}, \mathrm{K} 3,6 \mathrm{mmol} / \mathrm{L}, \mathrm{Ca} 9,3 \\
\mathrm{mmol} / \mathrm{L}, \mathrm{Cl} 110 \mathrm{mmol} / \mathrm{L}, \mathrm{Mg} 1,8 \mathrm{mmol} / \mathrm{L} \\
\text { Keseimbangan cairan: }+1453 .\end{array}$ & $\begin{array}{l}\text { Mode ventilator P-SIMV PS } 18, \text { PEEP } 8 \text {, setting } \\
\text { RR } 13, \mathrm{FiO}_{2} 50 \% \\
\text { Parasetamol infus } 1 \text { gram jika suhu }>38^{\circ} \mathrm{C} \text {. } \\
\text { Dilakukan kultur kuman dari darah. Hasil kultur : } \\
\text { tidak ada pertumbuhan bakteri. } \\
\text { Terapi lanjut. }\end{array}$ \\
\hline
\end{tabular}




\begin{tabular}{|c|c|c|}
\hline $\begin{array}{l}12-11-2014 \\
\text { (Hari ke-5) }\end{array}$ & $\begin{array}{l}\text { Kesadaran tersedasi. Hemodinamik stabil. Saturasi } 97 \\
-100 \% \text {. } \\
\text { Lab: Na } 141 \mathrm{mmol} / \mathrm{L}, \mathrm{K} 3,9 \mathrm{mmol} / \mathrm{L}, \mathrm{Ca} 9,7 \mathrm{mmol} / \mathrm{L}, \mathrm{Cl} \\
112 \mathrm{mmol} / \mathrm{L}, \mathrm{Mg} 2 \mathrm{mmol} / \mathrm{L} . \mathrm{CVP} 11 \mathrm{cmH} 2 \mathrm{O} \text {. Keseimban- } \\
\text { gan cairan: }+1547 .\end{array}$ & $\begin{array}{l}\text { Mode ventilator P-SIMV PS 18, } \\
\text { PEEP 8, RR 13, } \mathrm{FiO}_{2} 40 \% \text {. } \\
\text { Konsul jantung: suspek kar- } \\
\text { diomiopati, saran ekokardiografi } \\
\text { bila kondisi stabil. } \\
\text { Rokuronium dan midazolam dihen- } \\
\text { tikan } \\
\text { Tambah antibiotik Levofloxacin } 1 \mathrm{x} \\
750 \mathrm{mg} \text {. } \\
\text { Bila suhu }>38 \quad{ }^{\circ} \mathrm{C} \text { diberikan } \\
\text { paracetamol infus } 1 \text { gram, tetapi } \\
\text { kalau suhu }>39^{\circ} \mathrm{C} \text { maka selain di- } \\
\text { berikan paracetamol infus } 1 \text { gram, } \\
\text { berikan kompres badan dan gastric } \\
\text { cooling tiap } 3 \text { jam }\end{array}$ \\
\hline $\begin{array}{l}13-11-2014 \\
(\text { Hari ke-6) }\end{array}$ & $\begin{array}{l}\text { Kesadaran komposmentis. Hemodinamik stabil. TD } \\
\text { 114/74 mmHg, HR } 74 \text { x/menit, RR } 24 \text { x/menit, Saturasi } \\
\text { 99-100\%. } \\
\text { Lab: GD } 102 \mathrm{mg} / \mathrm{dl} . \\
\text { Keseimbangan cairan : + } 2570 \mathrm{cc} \text {. } \\
\end{array}$ & $\begin{array}{l}\text { Weaning ventilator, mode SIMV } \\
\text { PS 14, PEEP 6, RR 10, } \mathrm{FiO}_{2} 40 \% \text {. } \\
\text { Terapi lanjut } \\
\text { Ekstra injeksi furosemid } 20 \mathrm{mg} \\
\text { KaEN 3B diturunkan } 60 \mathrm{cc} / \mathrm{jam} . \\
\end{array}$ \\
\hline $\begin{array}{l}14-11-2014 \\
(\text { Hari ke-7) }\end{array}$ & $\begin{array}{l}\text { Kesadaran komposmentis. Hemodinamik relatif stabil. TD } \\
105 / 70 \mathrm{mmHg} \text {, HR } 83 \mathrm{x} / \mathrm{menit} \text {, RR } 23 \mathrm{x} / \text { menit, suhu } 36^{\circ} \mathrm{C} \text {. } \\
\text { Saturasi } 100 \% \text {. CVP } 11 \mathrm{~cm} \mathrm{H} \mathrm{H}_{2} \mathrm{O} \text {. Keseimbangan cairan: + } \\
945 .\end{array}$ & $\begin{array}{l}\text { Mode ventilator spontan, PS } 10 \text {, } \\
\text { PEEP } 8 \text {, FiO2 } 40 \% \text {. } \\
\text { Terapi lanjut } \\
\text { Meropenem diganti dengan } \\
\text { Ceftazidin } 3 \text { x } 2 \text { gram. }\end{array}$ \\
\hline $\begin{array}{l}15-11-2014 \\
(\text { Hari ke-8) }\end{array}$ & $\begin{array}{l}\text { Kesadaran komposmentis. Hemodinamik stabi. TD 108/60 } \\
\text { mmHg, HR 95x/menit, RR } 15 \text { x/menit, Saturasi 98-99\%. } \\
\text { Lab: Na } 134 \mathrm{mmol} / \mathrm{L}, \mathrm{K} 3,8 \mathrm{mmol} / \mathrm{L} \text {, Ca 10,4 mmol/L, } \\
\text { Cl } 106 \mathrm{mmol} / \mathrm{L}, \mathrm{Mg} 2 \mathrm{mmol} / \mathrm{L} \text {. Keseimbangan cairan: + } \\
2012 .\end{array}$ & $\begin{array}{l}\text { Mode ventilator spontan, PS } 8 \text {, } \\
\text { PEEP } 7, \mathrm{FiO}_{2} 40 \% \text {. } \\
\text { Terapi lanjut } \\
\text { Ekstra injeksi furosemid } 20 \mathrm{mg} \text {. }\end{array}$ \\
\hline \begin{tabular}{|l|}
$16-11-2014$ \\
(Hari ke-9)
\end{tabular} & $\begin{array}{l}\text { Kesadaran komposmentis. Hemodinamik stabil. TD } \\
\text { 100/60 mmHg, HR 69x/menit, RR } 18 \text { x/menit, Saturasi } 98 \\
-100 \% \text {. } \\
\text { Pasca ekstubasi : nafas spontan dengan } \mathrm{SM} \mathrm{O}_{2} 5 \text { liter/me- } \\
\text { nit saturasi } 97-99 \% \text {. } \\
\text { Lab: GD } 113 \mathrm{mg} / \mathrm{dl} \text {. } \\
\text { Keseimbangan cairan: }+1130 \mathrm{cc} \text {. }\end{array}$ & $\begin{array}{l}\text { Mode ventilator spontan, PS } 8 \text {, } \\
\text { PEEP 6, FiO2 40\%. } \\
\text { Jam } 17.00 \text { wite dilakukan ekstu- } \\
\text { basi. } \\
\text { Terapi lanjut } \\
\text { Dexametason } 3 \text { x } 4 \mathrm{mg} \\
\text { Ranitidin } 2 \text { x } 50 \mathrm{mg} .\end{array}$ \\
\hline $\begin{array}{l}\text { 17-11-2014 } \\
\text { (Hari ke-10) }\end{array}$ & $\begin{array}{l}\text { Kesadaran komposmentis. Hemodinamik stabil. TD } \\
\text { 100/60 mmHg, HR 69x/menit, RR } 18 \text { x/menit dengan } \\
\text { binasal kanul } 3 \text { liter/menit, saturasi } 98-100 \% \text {. } \\
\text { Lab: Hb 10,2 g/dL, WBC } 13.000 / \mu \mathrm{L}, \mathrm{Ht} 29,3 \% \text {, PLT } \\
496.000 / \mu \mathrm{L}, \mathrm{GD} 87 \mathrm{mg} / \mathrm{dL}, \mathrm{Albumin}: 5,4 \mathrm{~g} / \mathrm{dl} \text {, Ureum } \\
27,3 \mathrm{mg} / \mathrm{dl}, \mathrm{Kreatinin} 0,9 \mathrm{mg} / \mathrm{dl}, \mathrm{Na} 137 \mathrm{mmol} / \mathrm{L}, \mathrm{K} \\
\text { 4,3 mmol/L, Ca } 9,7 \mathrm{mmol} / \mathrm{L}, \mathrm{Cl} 104 \mathrm{mmol} / \mathrm{L}, \mathrm{Mg} 2,4 \\
\text { mmol/L. Keseimbangan cairan: }+1609 .\end{array}$ & $\begin{array}{l}\text { Terapi lanjut. } \\
\text { Hasil ekokardiografi : dalam batas } \\
\text { normal. }\end{array}$ \\
\hline $\begin{array}{l}8-11-2014 \\
(\text { Hari ke-11) }\end{array}$ & $\begin{array}{l}\text { Kesadaran komposmentis. Hemodinamik stabil. TD 90/59 } \\
\mathrm{mmHg} \text {, HR } 75 \mathrm{x} / \mathrm{m} \text { nit, RR } 20 \mathrm{x} / \mathrm{menit} \text { dengan binasal } \\
\mathrm{kanul} 3 \text { liter/menit, saturasi } 97-100 \% \text {. } \\
\mathrm{Lab}: \mathrm{Na} 136 \mathrm{mmol} / \mathrm{L}, \mathrm{K} 4,0 \mathrm{mmol} / \mathrm{L}, \mathrm{Ca} 9,9 \mathrm{mmol} / \mathrm{L}, \mathrm{Cl} 104 \\
\mathrm{mmol} / \mathrm{L}, \mathrm{Mg} 1,6 \mathrm{mmol} / \mathrm{L}, \mathrm{GD} 125 \mathrm{mg} / \mathrm{dL} \text {. Keseimbangan } \\
\text { cairan: + } 266 \text {. }\end{array}$ & $\begin{array}{l}\text { Terapi lanjut } \\
\text { Belajar makan peroral. }\end{array}$ \\
\hline
\end{tabular}




\begin{tabular}{|c|c|c|}
\hline $\begin{array}{l}\text { 19-11-2014 } \\
\text { (Hari ke-12 }\end{array}$ & $\begin{array}{l}\text { Kesadaran komposmentis. Hemodinamik stabil. TD } \\
90 / 59 \mathrm{mmHg} \text {, HR } 82 \mathrm{x} / \text { menit, RR } 18 \mathrm{x} / \text { menit dengan } \\
\text { binasal kanul } 3 \text { liter/menit, Saturasi } 97-100 \% \text {. } \\
\mathrm{CVP} 11 \mathrm{cmH}{ }_{2} \mathrm{O} \text {. } \\
\text { Lab: GD } 133 \mathrm{mg} / \mathrm{dL} \text {. } \\
\text { Keseimbangan cairan: + } 625\end{array}$ & $\begin{array}{l}\text { Terapi lanjut. } \\
\text { Injeksi Levofloxacin dihentikan }\end{array}$ \\
\hline $\begin{array}{l}20-11-2014 \\
\text { (Hari ke-13) }\end{array}$ & $\begin{array}{l}\text { Kesadaran komposmentis. Hemodinamik stabil. TD } \\
100 / 63 \mathrm{mmHg} \text {, HR } 60 \mathrm{x} / \text { menit, RR } 20 \mathrm{x} / \text { menit dengan } \\
\text { binasal kanul } 3 \text { liter/menit, Saturasi } 100 \% \text {. } \\
\text { CVP } 11 \mathrm{~cm} \mathrm{H}_{2} \mathrm{O} \text {. } \\
\mathrm{Lab}: \mathrm{Na} 133 \mathrm{mmol} / \mathrm{L}, \mathrm{K} 4,3 \mathrm{mmol} / \mathrm{L}, \mathrm{Ca} 9,4 \mathrm{mmol} / \mathrm{L} \text {, } \\
\mathrm{Cl} 102 \mathrm{mmol} / \mathrm{L}, \mathrm{Mg} 3,4 \mathrm{mmol} / \mathrm{L} \text {. } \\
\text { Keseimbangan cairan: }+524 .\end{array}$ & Terapi lanjut \\
\hline $\begin{array}{l}21-11-2014 \\
\text { (Hari ke-14) }\end{array}$ & $\begin{array}{l}\text { Kesadaran komposmentis. Hemodinamik stabil. TD } \\
110 / 70 \mathrm{mmHg} \text {, HR } 85 \mathrm{x} / \text { menit, RR } 20 \mathrm{x} / \text { menit dengan } \\
\text { binasal kanul } 3 \text { liter/menit, saturasi } 100 \% \text {. } \\
\text { CVP } 11 \mathrm{cmH}_{2} \mathrm{O} \text {. }\end{array}$ & $\begin{array}{l}\text { Pasien pindah ke ruang perawatan } \\
\text { biasa. }\end{array}$ \\
\hline $\begin{array}{l}23-11-2014 \\
\text { (Hari ke-16) }\end{array}$ & $\begin{array}{l}\text { Pasien dipulangkan dengan kondisi TD 105/60 mmHg, } \\
\text { HR } 78 \text { x/menit, RR } 18 \text { x/menit, Sat 98\% dengan udara } \\
\text { ruangan }\end{array}$ & CVP dilepas. \\
\hline
\end{tabular}

Kemudian pasien ditransfer ke ICU. Setelah sampai di ICU (jam 05.00 WITE), ETT pasien dihubungkan dengan ventilator mode SIMV, tidal volume 450, PEEP 8, RR 18 dan $\mathrm{FiO}_{2}$ $100 \%$. Keadaan pasien tampak lemah, kesadaran composmentis, kemudian dilakukan pemasangan monitor, tekanan darah $121 / 78 \mathrm{mmHg}$, laju nadi $125 \mathrm{x} /$ menit, laju nafas $26-27 \mathrm{x} /$ menit dan saturasi $62 \%$. Diberikaan injeksi meropenem 2x1 gram, morpin $1 \mathrm{mg} / \mathrm{jam}$. Keseimbangan cairan: $958 \mathrm{cc}$ (input: $242 \mathrm{cc}$, output: $1200 \mathrm{cc}$ ).

\section{Patofisiologi}

Udem paru akut adalah keadaan patologi dimana cairan intravaskuler keluar ke ruang ektravaskuler, jaringan interstisial dan alveoli yang terjadi secara akut dan dalam jumlah yang banyak. Akumulasi cairan ini akan berakibat serius pada fungsi paru oleh karena tidak mungkin terjadi pertukaran gas apabila alveoli penuh terisi cairan. Pada keadaan normal cairan intravaskuler merembes ke jaringan interstitial melalui kapiler endotelium dalam jumlah yang sedikit sekali, kemudian cairan ini akan mengalir ke pembuluh limfe menuju ke vena pulmonalis untuk kembali kedalam sirkulasi. Mekanisme yang menjaga agar jaringan interstisial tetap kering adalah: ${ }^{2}$ tekanan onkotik plasma lebih tinggi daripada

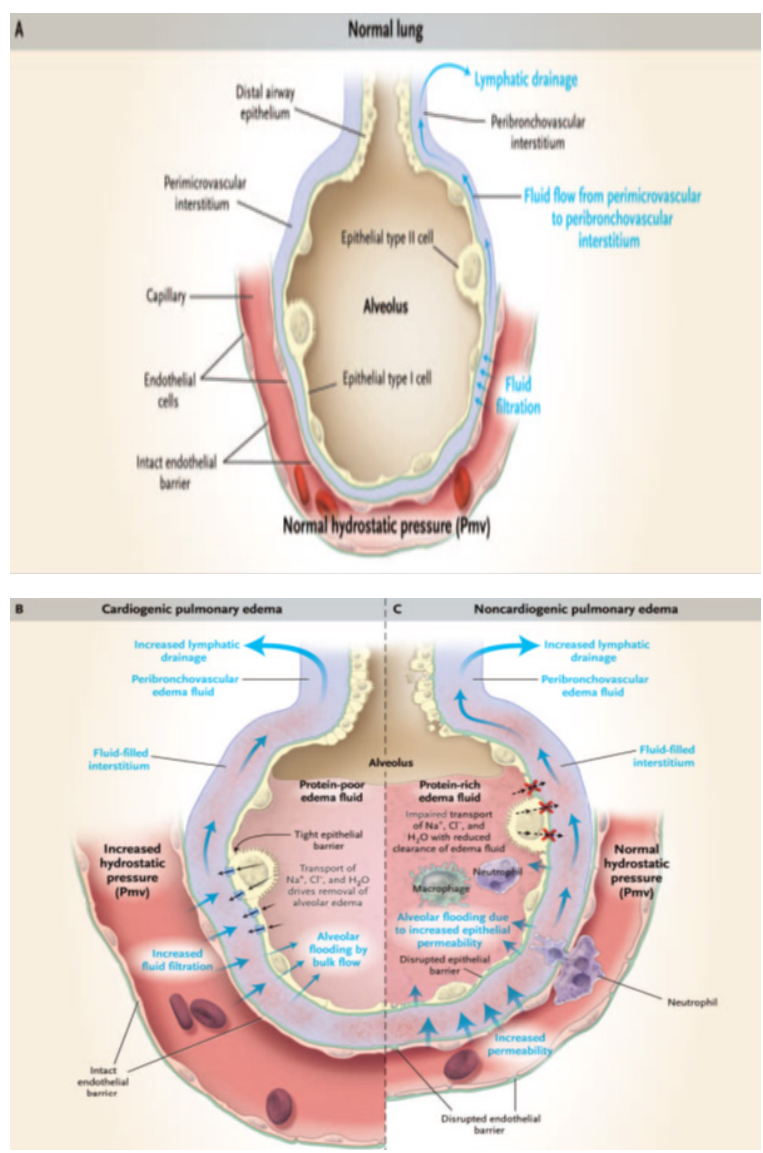

Gambar 1. Gambaran alveoli pada paru normal dan perubahan alveoli pada udem paru kardiogenik dan udem paru non kardiogenik. ${ }^{2}$ 
Tabel 1. Beda Gambaran Radiologi Udem Paru Kardigenik dan Non Kardiogenik

\begin{tabular}{lll}
\hline Gambaran Radiologi & Udem Kardiogenik & Udem Non Kardiogenik \\
\hline Ukuran jantung & Normal atau membesar & Biasanya normal \\
Lebar pedikel vaskuler & Normal atau melebar & Biasanya normal \\
Distribusi vaskuler & Seimbang & Normal/seimbang \\
Distribusi Udem & Rata/sentral & Patchy atau perifer \\
Efusi pleura & Ada & Biasanya tidak ada \\
Peribronchial cuffing & Ada & Biasanya tidak ada \\
Garis septal & Ada & Biasanya tidak ada \\
Air bronchogram & Tidak selalu ada & Selalu ada \\
\hline
\end{tabular}

tekanan hidrostatik kapiler paru, jaringan konektif dan barier seluler relatif tidak permeabel terhadap protein plasma, adanya sistem limfatik yang secara ekstensif mengeluarkan cairan dari jaringan interstisial. Pada keadaan normal tekanan kapiler pulmonal (wedge pressure) adalah sekitar 7 dan $12 \mathrm{~mm} \mathrm{Hg}$. Karena tekanan onkotik plasma berkisar antara $25 \mathrm{mmHg}$, maka tekanan ini akan mendorong cairan kembali kedalam kapiler. Tekanan hidrostatik bekerja melewati jaringan konektif dan barier seluler, yang dalam keadaan normal bersifat relatif tidak permeabel terhadap protein plasma. Paru mempunyai sistem limfatik yang secara ekstensif dapat meningkatkan aliran 5 atau 6 kali bila terjadi kelebihan air di dalam jaringan interstisial paru. Udem paru akan terjadi bila mekanisme normal untuk menjaga paru tetap kering terganggu oleh keadaan: ${ }^{2}$ Permeabiltas membran yang berubah, tekanan hidrostatik mikrovaskuler yang meningkat, tekanan peri mikrovaskuler yang menurun, tekanan osmotik/ onkotik mikrovaskuler yang menurun, tekanan

Tabel 2. Faktor Resiko dan Predisposisi terjadinya Udem Paru Akut pada Wanita Hamil

\begin{tabular}{|c|c|}
\hline Kategori & Faktor Resiko \\
\hline \multirow[t]{4}{*}{ Kondisi penyakit sebelum hamil } & $\begin{array}{l}\text { Penyakit Jantung (hipertensi, penyakit jantung iskemik, } \\
\text { penyakit jantung kongenital, kelainan katup jantung, } \\
\text { aritmia, kardiomiopati) }\end{array}$ \\
\hline & Obesitas \\
\hline & Peningkatan umur ibu \\
\hline & Gangguan endokrin (peokromositoma dan hipertiroid) \\
\hline \multirow[t]{6}{*}{ Penyakit spesifik selama kehamilan } & Preeklamsi dan eklamsi \\
\hline & Kardiomiopati \\
\hline & Sepsis \\
\hline & Persalinan prematur \\
\hline & Emboli air ketuban \\
\hline & Emboli paru \\
\hline \multirow[t]{4}{*}{ Obat farmakologi } & B-Adrenergic tocolytic agents \\
\hline & Kortikosteroid \\
\hline & Magnesium sulfat \\
\hline & Narkotik \\
\hline Cairan intravena iatrogenik & Cairan lebih dari $2000 \mathrm{cc}$ \\
\hline Kondisi fetus & Kehamilan ganda \\
\hline
\end{tabular}




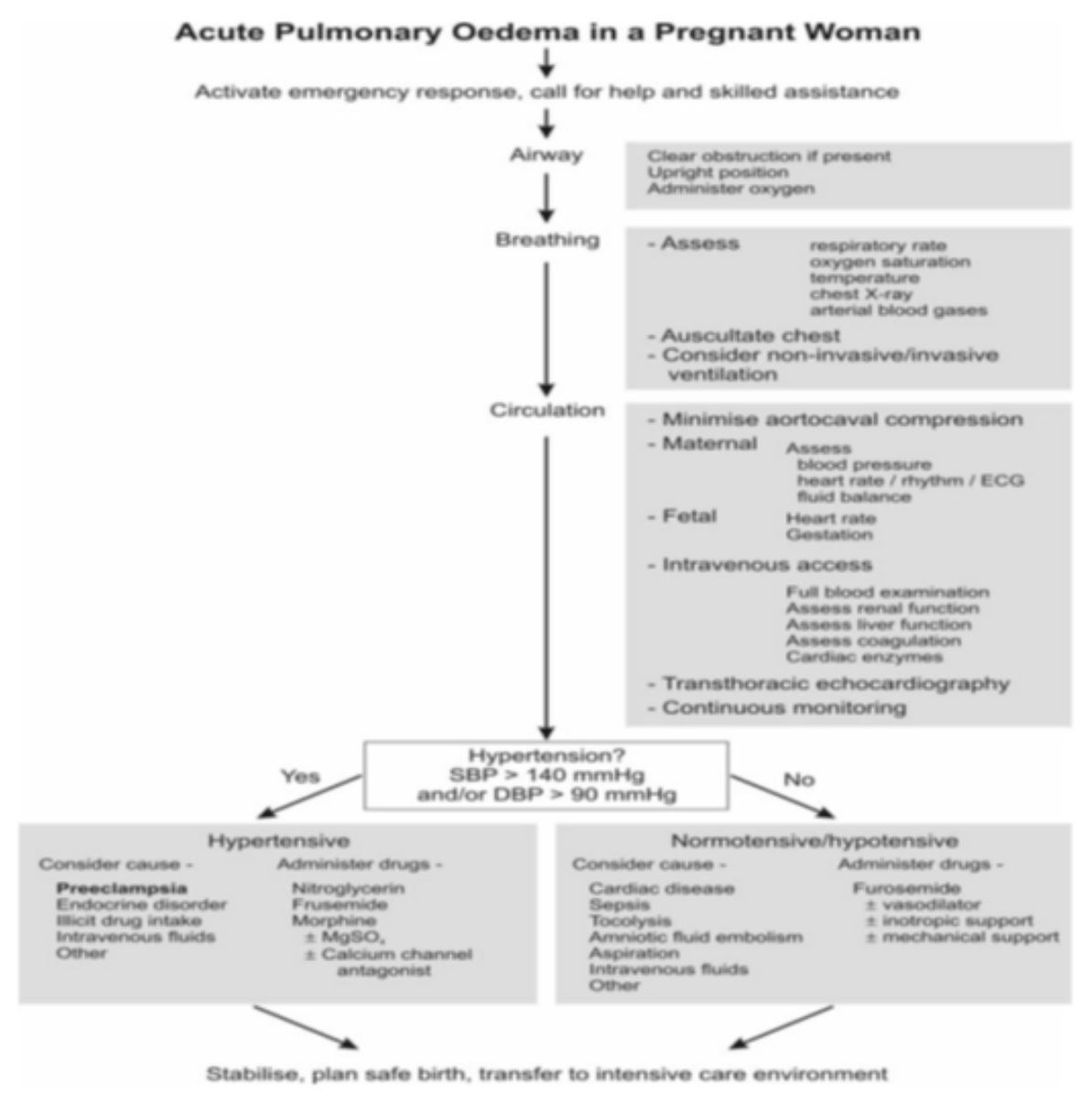

Gambar 2. Alur Penanganan Wanita Hamil dengan Udem Paru Akut

osmotik/onkotik peri mikrovaskuler yang meningkat, gangguan saluran limfe. Udem paru akut dapat terjadi karena penyakit jantung (disebut juga udem paru kardiogenik, udem hidrostatik atau udem hemodinamik) maupun penyakit diluar jantung (udem paru non kardiogenik disebut juga increased permeability pulmonary edema, acute lung injury atau acute respiratory distress syndrome). Meskipun penyebabnya berbeda, udem paru kardiogenik dan non kardiogenik sulit dibedakan karena memiliki manifestasi klinis yang sama. ${ }^{2}$

Perbedaan mikrovaskuler dan alveoli pada paru normal, pada paru yang mengalami udem paru akut kardiogenik dan pada udem paru akut non kardiogenik dapat dilihat pada gambar dibawah ini. Kedua jenis udem paru ini berbeda secara patogenesis dan patofisiologi meskipun secara klinis sulit dibedakan karena mempunyai manifestasi klinis yang sama. Bahkan sering kedua jenis udem paru ini terjadi bersamaan. Membedakan kedua jenis udem paru tersebut membutuhkan pemantauan hemodinamik invasif. Gambaran rontgen paru bisa membantu membedakan udem paru kardiogenik dan udem paru non kardiogenik. Walaupun tetap ada keterbatasan yaitu antara lain bahwa udem tidak akan tampak secara radiologi sampai jumlah air di paru meningkat 30\%. Beberapa masalah teknis juga dapat mengurangi sensitivitas dan spesifisitas rontgen paru seperti rotasi, inspirasi, ventilator, posisi pasien dan posisi film. Perbedaan udem paru kardiogenik dan non kardiogenik dapat dilihat pada tabel $1 .{ }^{3,4}$

Berdasarkan hasil audit tentang morbiditas maternal di Inggris, udem paru merupakan empat besar penyebab morbiditas pada maternal, dan sering kali membutuhkan perawatan di 
OPEN LUNG TOOL (OLT) GUIDELINES

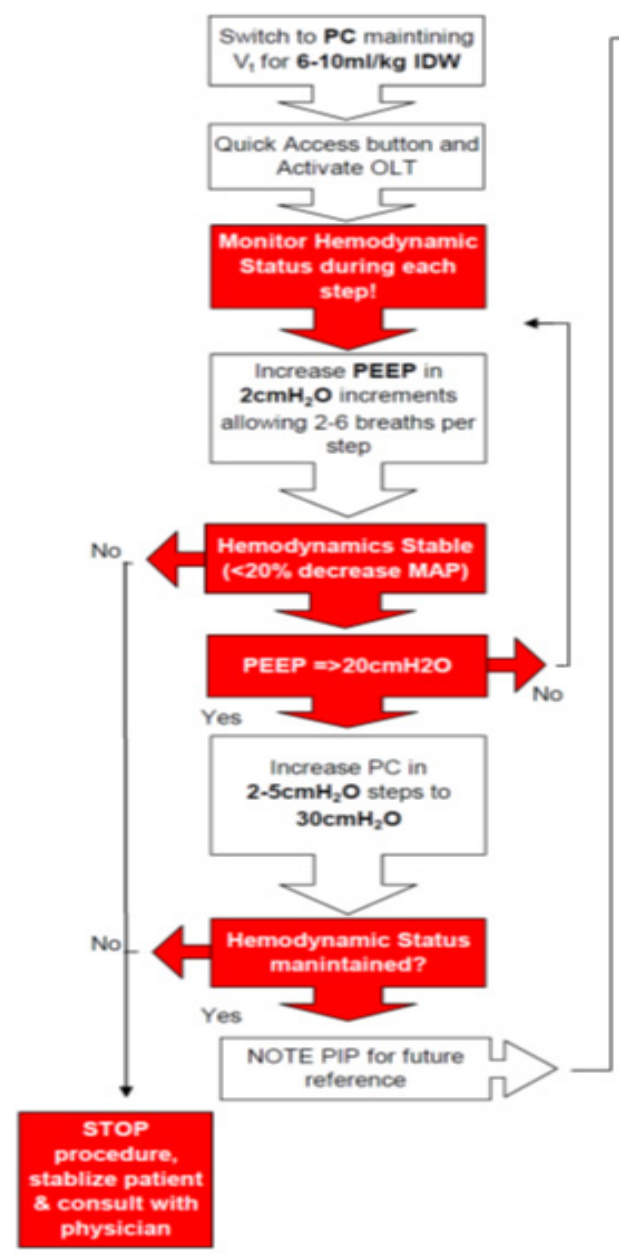

ruang intensif. ${ }^{5}$ Udem paru bisa terjadi pada periode antenatal, intrapartum dan periode pasca persalinan. Insidensi udem paru bervariasi antara 0,08-0,5\%. ${ }^{6}$ Faktor resiko dan predisposisi terjadinya udem paru akut pada wanita hamil dapat dilihat pada tabel $2 .{ }^{6}$ Selain faktor resiko diatas masih ada beberapa hal yang diduga menjadi penyebab udem paru, antara lain tranfusi darah, serta penggunaan oksitosin peripartum walaupun tanpa disertai adanya kejadian kelebihan cairan dalam vaskuler ataupun penyakit jantung. ${ }^{7}$ Walaupun tidak ada terapi yang spesifik untuk menghentikan proses inflamasi yang terjadi pada udem paru, penanganan udem paru difokuskan pada 3 hal penting yaitu: ${ }^{7}$ mencegah lesi paru secara iatrogenik, mengurangi cairan di dalam paru, mempertahankan oksigenasi jaringan.

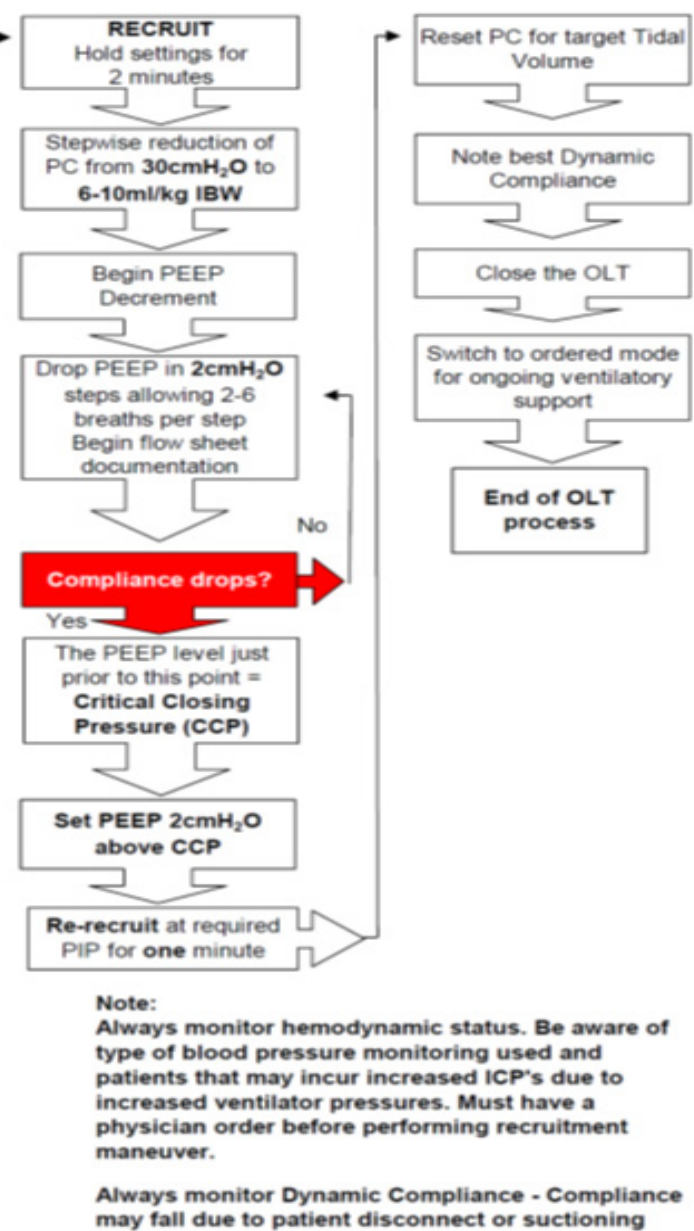

Pendekatan terapi terkini untuk udem paru adalah meliputi perawatan suportif, bantuan ventilator dan terapi farmakologis. ${ }^{8}$ Prinsip umum perawatan suportif bagi pasien udem paru dengan atau tanpa multiple organ dysfungsi syndrome (MODS) meliputi: ${ }^{8}$ Pengidentifikasian dan terapi penyebab dasar udem paru; menghindari cedera paru sekunder misalnya aspirasi, barotrauma, infeksi nosokomial atau toksisitas oksigen; memperbaiki hemodinamik untuk meningkatkan oksigenasi dengan memberikan cairan, obat-obatan vasodilator atau obat-obatan vasokonstriktor, inotropik, atau diuretikum; mempertahankan penghantaran oksigen yang adekuat ke end-organ dengan cara meminimalkan angka metabolik; sedasi dengan kombinasi opiat benzodiazepin, oleh karena penderita 
akan memerlukan bantuan ventilasi mekanik dalam jangka lama. Berikan dosis minimal yang masih memberikan efek sedasi yang adekuat; mengoptimalkan fungsi kardiovaskuler serta keseimbangan cairan tubuh; dukungan nutrisi.

Pendekatan dalam penggunaan model ventilasi mekanis pada pasien udem paru masih kontroversial. ${ }^{9}$ Open lung recruitment merupakan salah satu tehnik dalam penanganan udem paru, tetapi hal ini juga masih kontroversial. Pendapat yang mendukung tehnik ini, mengatakan bahwa tehnik ini efektif dan aman digunakan pada pasien tertentu. Dengan tehnik ini diharapkan dapat mengurangi udem paru dan meningkatkan hasil akhir penatalaksanaan udem paru. Open lung recruitment juga dapat meningkatkan oksigenasi pada pasien dengan udem paru akut, dapat menurunkan indeks cairan ekstravaskuler paru, meningkatkan pengembangan paru dan menurunkan tekanan pada jalan nafas. ${ }^{10}$ Sementara pendapat yang berbeda mengatakan bahwa tehnik ini tidak aman dan tidak ada data yang menunjukkan bahwa tehnik ini memberikan perbaikan pada hasil akhir dalam penatalaksanaan udem paru. ${ }^{11}$ Prinsip pengaturan ventilator pasien udem paru meliputi volume tidal rendah $(4-6 \mathrm{~mL} /$ $\mathrm{kgBB}$ ) dan PEEP yang adekuat, kedua pengaturan ini dimaksudkan untuk memberikan oksigenasi adekuat $\left(\mathrm{PaO}_{2}>60 \mathrm{mmHg}\right)$ dengan tingkat $\mathrm{FiO}_{2}$ aman, menghindari barotrauma (tekanan saluran napas $<35 \mathrm{cmH}_{2} \mathrm{O}$ atau di bawah titik refleksi dari kurva pressure-volume) dan menyesuaikan (I:E) rasio inspirasi: ekspirasi (lebih tinggi atau kebalikan rasio waktu inspirasi terhadap ekspirasi dan hiperkapnea yang diperbolehkan). ${ }^{8,12,13}$ Secara garis besar penanganan udem paru akut pada wanita hamil bisa dilihat pada gambar 2 dibawah ini. ${ }^{6}$

\section{Pembahasan}

Saat masuk UGD pasien ini didiagnosis sebagai udem paru akut pada wanita pasca operasi sesar. Ada beberapa faktor resiko yang dicurigai menjadi penyebab dari udem paru akut pada pasien ini, antara lain pasien ini dilakukan operasi sesar atas indikasi PEB6, penggunaan oksitosin peripartum7 dan pasien juga mendapatkan tranfusi darah pasca operasi sesar7. Seperti telah dijelaskan diatas bahwa beberapa penyakit spesifik selama kehamilan dapat menjadi faktor resiko terjadinya udem paru akut. Penyakit spesifik tersebut seperti preeklamsi dan eklamsi, kardiomiopati, sepsis, persalinan prematur, emboli air ketuban dan emboli paru. Insiden udem paru pada wanita dengan preeklamsi sekitar 3\%, dimana $70 \%$ terjadi setelah persalinan. Dibandingkan dengan wanita hamil yang sehat, wanita dengan preeklamsi menunjukkan keadaan jantung yang abnormal, dari peningkatan kardiak output dan peningkatan systemic vascular resistance (SVR) sampai ke penurunan kardiak output dengan peningkatan systemic vascular resistance. Fungsi diastolik terganggu. Preeklamsi juga menyebabkan penurunan tekanan osmotik koloid plasma, perubahan permeabilitas endotel dan penurunan tekan osmotik koloid terhadap left ventricular end diastolic pressure gradient. Sehingga mudah terjadi kebocoran kedalam interstisial paru dan ruang alveoli. ${ }^{6}$ Penggunaan magnesium sulfat (MgSO4) intravena pada pasien-pasien dengan preeklamsi juga memicu terjadinya udem paru, mekanismenya karena penurunan tekanan osmotik koloid dan efek inotropik negatif. . $^{1415}$ Dengan adanya perubahan pada permeabilitas endotel pembuluh darah karena preeklamsi, maka sebaiknya hati-hati dalam hal penggunaan cairan intravena ataupun produk darah pada pasien dengan preeklamsi, karena kedua hal tersebut dapat memicu terjadinya udem paru. ${ }^{6,7}$

Penggunaan oksitosin peripartum bisa diduga menjadi pemicu udem paru. Efek oksitosin selain memperbaiki kontraksi rahim, juga mempunyai efek sistemik seperti relaksasi pembuluh darah sehingga menyebabkan terjadinya vasodilatasi, yang menyebabkan penurunan tekanan darah terutama tekanan darah diastolik, disamping itu juga menimbulkan efek takikardi. Oksitosin juga mempunyai efek anti diuretik bila diberikan dalam dosis besar. Pernah dilaporkan juga bahwa oksitosin dapat menyebabkan intoksikasi air dengan hiponatremi sekunder sampai retensi cairan bebas, sehingga dapat mengakibatkan udem paru, kejang, koma dan kematian. Pada dosis yang fisiologis, tanpa disertai peningkatan status volume, oksitosin jarang menyebabkan 
aksi anti diuretik. Meskipun demikian, penggunaan oksitosin peripartum dapat memicu udem paru walaupun tanpa disertai overloading vascular atau penyakit jantung. Sehingga penggunaan oksitosin tetap harus hati-hati. ${ }^{7}$ Pendekatan terapi terkini untuk udem paru adalah meliputi perawatan suportif, bantuan ventilator dan terapi farmakologis. ${ }^{8}$ Pendekatan dalam penggunaan model ventilasi mekanis pada pasien udem paru masih kontroversial. ${ }^{9}$ Open lung recruitment merupakan salah satu tehnik dalam penanganan udem paru, tetapi hal ini juga masih kontroversial. Pendapat yang mendukung tehnik ini, mengatakan bahwa tehnik ini efektif dan aman digunakan pada pasien tertentu. Open lung recruitment juga dapat meningkatkan oksigenasi pada pasien dengan udem paru akut, dapat menurunkan indeks cairan ekstravaskuler paru, meningkatkan pengembangan paru dan menurunkan tekanan pada jalan nafas. ${ }^{10}$

Sementara pendapat yang berbeda mengatakan bahwa tehnik ini tidak aman dan tidak ada data yang menunjukkan bahwa tehnik ini memberikan perbaikan pada hasil akhir dalam penatalaksanaan udem paru. ${ }^{11}$ Prinsip pengaturan ventilator pasien udem paru meliputi volume tidal rendah $(4-6 \mathrm{~mL} /$ $\mathrm{kgBB}$ ) dan PEEP yang adekuat, kedua pengaturan ini dimaksudkan untuk memberikan oksigenasi adekuat $\left(\mathrm{PaO}_{2}>60 \mathrm{mmHg}\right)$ dengan tingkat $\mathrm{FiO}_{2}$ aman, menghindari barotrauma (tekanan saluran napas $<35 \mathrm{cmH}_{2} \mathrm{O}$ atau di bawah titik refleksi dari kurva pressure-volume) dan menyesuaikan (I:E) rasio inspirasi: ekspirasi (lebih tinggi atau kebalikan rasio waktu inspirasi terhadap ekspirasi dan hiperkapnea yang diperbolehkan). ${ }^{8,12,13}$ Pada awalnya pasien ini telah dilakukan terapi sesuai yang telah dijelaskan diatas, tetapi berhubung pada hari kedua pasien masih mengalami hipoksemia yang ditandai dengan saturasi yang tidak pernah baik, maka diputuskan untuk dilakukan open lung recruitment. Pada saat melakukan tehnik ini, monitoring terhadap perubahan hemodinamik tetap harus dilakukan. Selama dilakukan tehnik ini, hemodinamik pasien dalam keadaan stabil. Pasien juga menunjukkan perbaikan keadaan dimana saturasi pasien meningkat dan kebutuhan $\mathrm{FiO}_{2}$ bisa diturunkan secara bertahap. Respon yang baik ini diikuti dengan perbaikan kondisi pasien yang lainnya. Perawatan suportif dan terapi farmakologis harus dilakukan secara simultan. Pada hari kelima perawatan, obat sedasi dan pelumpuh otot dihentikan, sehingga hari keenam pasien bisa dilakukan penyapihan dari ventilator. Dan hari ke sembilan pasien bisa di ekstubasi. Hari ke 14 pasien pindah ke ruang perawatan biasa. Dan 2 hari kemudian pasien bisa pulang ke rumah dengan perbaikan yang nyata.

\section{Simpulan}

Udem paru akut merupakan indikator morbiditas yang nyata dan bisa menjadi penyebab mortalitas pada wanita hamil. Pengenalan dini tanda-tanda terjadinya udem paru bisa membantu dalam penatalaksanaan udem paru sehingga bisa ditangani lebih cepat dan bisa memberikan prognosis yang baik. Pendekatan terapi terkini untuk udem paru adalah meliputi perawatan suportif, bantuan ventilator dan terapi farmakologis. Salah satu tehnik yang digunakan dalam penatalaksaan udem paru adalah open lung recruitment, dimana tehnik ini dapat meningkatkan oksigenasi pada pasien, dapat menurunkan indeks cairan ekstravaskuler paru, meningkatkan pengembangan paru dan menurunkan tekanan pada jalan nafas. Tetapi penggunaan tehnik ini sampai saat ini masih kontroversial.

\section{Daftar Pustaka}

1. Anthony CS, Thomas I, Marissa L, James M. Acute pulmonary edema in pregnancy. The American College of Obstetricians and Gynecology. Elsevier Mosby-Philadelphia, Pennsylvania 2003;101(3): 511-5.

2. Lorraine BW, Michael AM. Acute pulmonary edema. N. Engl. J. Med. 2005;353:2788-96.

3. Milne EN, Pistolesi M, Miniati M, Giuntini C. The radiologic distinction of cardiogenic and noncardiogenic edema. American Lournal Roentgrnologi 1985;144:879-94.

4. Pistolesi M, Miniati M, Giuntini C. The chest roentgenogram in pulmonary edema. Clinical 
chest medicine 1985;6:315-44.

5. Cantwell R, Clutton BT, Cooper G. Saving mother's lives: reviewing maternal deaths to make motherhood safer:2006-2008. The eighth report of the confidential enquiries into maternal deaths in the United Kingdom. British Journal of Obstetrics and Gynaecology 2011;118(suppl 1): 1-203.

6. Dennis AT, Solnordal CB. Acute pulmonary oedema in pregnant women. Anaesthesia 2012;67:646-59.

7. Sinha N, Puri R, Shukla D, Kumar D, Sahu S, Agarwal A. Perioperative management of pulmonary oedema due to oxytocinin case of caesarean section. The Indian Journal of Research and Reports in Medical Sciences 2013;3(4):45-7.

8. Gehlbach BK. Acute hypoxemic respiratory failure (AHRF). Available at: http:/www. merck.com/mmpe/sec06/ch065/ch065. Accessed on January 5th,2008.

9. Piantadosi CA, Schwartz DA. The acute respiratory distress syndrome. Annals of Internal Medicine Journal 2004;141:460-70.

10. Zhang JG, Chen XJ, Zeng ZG, Qian KJ.
Lung recruitment maneuver effecs on respiratory mechanics and extravascular lung water index in patients with acute respiratory distress syndrome. World Journal Emergency Medicine 2011;2(3):201-5.

11. Robert MK, Richard HK. Should recruitment maneuvers be used in the management of ALI and ARDS?. Respiratory Care 2007;52(5):622-31.

12. Oh TE. Adult respiratory distress syndrome. In: Oh TE,ed. Intensive Care Manual. 3rd ed. Brisbane: Butterworths Pty Ltd;1990:174-7.

13. Gattinoni L, Caironi P, Carlesso E. How to ventilate patients with acute lung injury and acute respiratory distress syndrome. Current Opinion in Critical Care 2005; 11:69-76.

14. Gupta V. Does magnesium supplementation have any role in acute myocardial infarction? No. Cardiovascular Drugs Therapy 1996;10:303-305.

15. Thornton CE, Peter VD, Makris A, Tooher JM. Acute pulmonary oedema as a complication of hypertension during pregnancy. Hypertension in Pregnancy 2009:1-13. 